\title{
Preparation of $\mathrm{PBI} / \mathrm{H}_{3} \mathrm{PO}_{4}$-PTFE Composite Membranes for High Temperature Fuel Cells
}

\author{
Tzyy-Lung Leon $\mathrm{Yu}^{*}$ and Hsiu-Li Lin
}

Department of Chemical Engineering \& Materials Science, Fuel Cells Center, Yuan Ze University, Nei-Li, Chung-Li, Taoyuan 32003, Taiwan

\begin{abstract}
The poly(benzimidazole) (PBI)/ poly(tetrafluoroethylene) (PTFE) composite membrane was prepared by impregnating a porous PTFE thin film in a PBI solution N,N'-dimethyl acetamide (DMAc) solution mixed with LiCl. $\mathrm{LiCl}$ was used as a stabilizer to avoid aggregations of PBI molecules in the DMAc solutions. In this paper, we report a 2 $\mathrm{mg} / \mathrm{ml} \mathrm{PBI} / \mathrm{DMAc} / \mathrm{LiCl}$ solution with a $[\mathrm{LiCl}] /[\mathrm{BI}]$ molar ratio of $\sim 8.0$ (i.e. the $\mathrm{LiCl} / \mathrm{PBI}$ is $\sim 1.1$ in wt ratio, where $[\mathrm{BI}]$ is the concentration of benzimidazole repeat unit in the solution) has a lowest PBI polymer aggregations and thus a lowest solutions viscosity. The PBI membrane and PBI/PTFE composite membrane prepared from the PBI/DMAc/LiCl solution with a $[\mathrm{LiCl}] /[\mathrm{BI}]$ molar ratio of $\sim 8.0$ were used to dop $\mathrm{H}_{3} \mathrm{PO}_{4}$ and prepare membrane electrode assemblies (MEA). The unit cell performances of these MEAs were carried out at $150^{\circ} \mathrm{C}$. Owing to the high mechanical strength of porous PTFE, the thickness of $\mathrm{PBI} / \mathrm{H}_{3} \mathrm{PO}_{4}$ - $\mathrm{PTFE}$ composite membrane is allowed to be lower than that of a $\mathrm{PBI} / \mathrm{H}_{3} \mathrm{PO}_{4}$ membrane. The lower thickness of $\mathrm{PBI} / \mathrm{H}_{3} \mathrm{PO}_{4}$-PTFE membrane than that of $\mathrm{PBI} / \mathrm{H}_{3} \mathrm{PO}_{4}$ membrane results in a lower resistance of $\mathrm{PBI} / \mathrm{H}_{3} \mathrm{PO}_{4}$ - $\mathrm{PTFE}$ than $\mathrm{PBI} / \mathrm{H}_{3} \mathrm{PO}_{4}$. Thus the MEA prepared from $\mathrm{PBI} / \mathrm{H}_{3} \mathrm{PO}_{4}-\mathrm{PTFE}$ has a better fuel cell performance than that prepared from PBI.
\end{abstract}

Keywords: Poly(benzimidazole), PTFE, composite membrane, fuel cell.

\section{INTRODUCTION}

It is generally accepted that proton exchange membrane fuel cell (PEMFC) presents an attractive alternative to traditional power sources, due to its simplicity, high efficiency and non-pollution. The key component of a PEMFC is the membrane electrode assembly (MEA) which consists of a proton exchange membrane (PEM) located between two porous, electrically conductive electrodes [1-3]. The PEM is usually a polyelectrolyte or an ionomer. One of the most successful PEM for PEMFC is Nafion (a trade name of Du Pont Co). It is a perfluorosulfonated ionomer using water as proton conducting carriers and has an excellent proton conductivity and fuel cell performance at temperatures below $90^{\circ} \mathrm{C}$ with high humidity. However when working at temperatures above $100^{\circ} \mathrm{C}$, Nafion looses its capability for proton transport due to the loose of humidity at high temperatures.

Instead of using Nafion as a PEM for PEMFC, the use of hydrocarbon polymers for polymer backbones had generally been accepted to be another route to high performance proton conducting PEMs [4]. One of the most promising hydrocarbon polymer PEMs is phosphoric acid doped polybenzimidazole ( $\mathrm{PBI} / \mathrm{H}_{3} \mathrm{PO}_{4}$ ) membrane. It was first successfully used in high temperature $\left(140 \sim 180^{\circ} \mathrm{C}\right)$ PEMFC by Savinell and Litt group in early 1990 [5-9]. The chemical structure of $\mathrm{PBI}$ is shown in Fig. (1). In $\mathrm{PBI} / \mathrm{H}_{3} \mathrm{PO}_{4}$ membrane, phosphoric acid acts as protons conducting

*Address correspondence to this author at the Department of Chemical Engineering \& Materials Science, Nei-Li, Chung-Li, Taoyuan 32003, Taiwan; Tel: +886-3-4638800, Ext. 2553; Fax: +886-3-4559373;

E-mail: cetlyu@saturn.yzu.edu.tw carrier and no water is needed for protons conduction. Thus PEMFCs using PBI/ $\mathrm{H}_{3} \mathrm{PO}_{4}$ membranes as protonconducting separators are available to work at high temperatures $\left(100^{\circ} \mathrm{C}<\mathrm{Temp}<200^{\circ} \mathrm{C}\right)$ and low humility environment $[9,10]$.

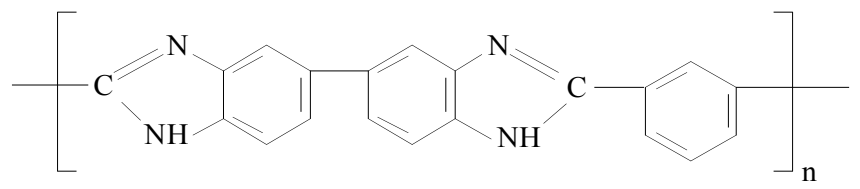

Fig. (1). The chemical structure of a repeat unit BI of PBI.

The advantages of high temperature working PEMFCs are [11]: (1) lower CO adsorption of catalysts leading to lower CO poison of catalysts, thus higher efficiency of catalysts; (2) lower heat exchange area needed to dissipate excess heat; and (3) the electrochemical reaction product, i.e. water, is easier to be evaporated at higher temperatures, thus easier water management. The lower $\mathrm{CO}$ adsorption of catalyst at higher temperatures leads the fuel cell easier to be operated with a liquid fuel reformer, which for kinetic reasons is run at a high temperature, yielding a significant amount of $\mathrm{CO}$. The lower heat exchange area and easy water management results in a simple design of fuel cells systems.

It had been shown that porous poly(tetrafluoro ethylene) (PTFE) thin film reinforced Nafion composite membranes could be prepared by impregnating a microporous thin film support with a Nafion solution [11-18]. It is important to note that the Nafion/PTFE (thickness around $\sim 20 \mu \mathrm{m}$ ) composite membranes contain much less of the expensive Nafion resin than the traditional Nafion membranes such as Nafion-117 (thickness $175 \mu \mathrm{m}$ ) and Nafion-212 (thickness $50 \mu \mathrm{m})$. Thus the cost of composite membranes is much 
lower than that of the traditional Nafion membranes. Besides the cheap cost, other advantages of the composite membranes are: good mechanical strength in both swollen and unswollen state, good thermo-stability, and thinner thickness (thickness $\sim 20 \mu \mathrm{m}$ ). Although the roomtemperature conductivity of a 1100 EW Gore-Select Nafion/PTFE membranes is lower than that of a Nafion membrane, the resistance of the whole membrane of a Nafion/PTFE composite membrane is significantly lower than that of a Nafion membrane due to the thinness of the Nafion/PTFE composite membrane.

Following the preparation of Nafion/PTFE composite membranes, Lin and $\mathrm{Yu}$ et al. [19-20] reported the preparation and application of PBI/PTFE composite membrane (thickness 25 30 $\mu \mathrm{m}$ ) to high temperature $\left(140 \sim 180^{\circ} \mathrm{C}\right)$ PEMFC. The reinforcement of PBI membranes with high mechanic strength porous PTFE thin film (thickness $16 \sim 20 \mu \mathrm{m}$ ) allows one to reduce the membrane thickness without losing mechanic strength. The low thickness of a PEM causes a reduction in the resistance of PEM and an improvement of fuel cells performance.

The PBI/PTFE composite membranes are prepared by impregnation porous PTFE support thin films in PBI solutions. Thus the properties of the impregnated membranes are strongly influenced by the properties of PBI solutions. In this paper, we reported the PBI solutions properties, the preparation of $\mathrm{PBI} / \mathrm{PTFE}$ composite membranes, and the application of composite membranes to PEMFC.

\section{EXPERIMENTAL}

\subsection{Synthesis of PBI}

PBI was synthesized from 3,3'-diamino benzidine (Aldrich Chemical Co) and isophthalic acid (Aldrich Chemical Co) using polyphosphoric acid (Aldrich Chemical Co) as a solvent. The detailed polymerization procedures were same as those reported by Ueda et al. [21]. The inherent viscosity (I.V.) was determined by dissolving 0.5 $w t \%$ of PBI in 98 wt $\%$ sulfuric acid solution using an Ubbelohde viscometer (with a water flow time of $98 \mathrm{sec}$ ) and an I.V. of $1.58 \mathrm{dL} / \mathrm{g}$ was obtained, which corresponded to $\mathrm{M}_{\mathrm{v}}=1.03 \times 10^{5} \mathrm{~g} / \mathrm{mol}$ calculated using an equation derived by Choe et al. [22].

\subsection{Preparation of $\mathrm{PBI} / \mathrm{DMAc} / \mathrm{LiCl}$ Solutions}

$\mathrm{PBI} / \mathrm{DMAc} / \mathrm{LiCl}$ solutions with a PBI concentration of 2 $\mathrm{mg} / \mathrm{ml}$ and various concentrations of $\mathrm{LiCl}$ (Riedel-deHaën Co, Germany) were prepared by mixing PBI with N,N'dimethyl acetamide (DMAc, Fluka Chemical Co, Japan) and $\mathrm{LiCl}$. Wherein the molar ratios of $[\mathrm{LiCl}] /[\mathrm{BI}]$ were 3.63 , $5.00,6.00,7.26,8.00,9.07,10.88$, and 14.51 (BI is the repeat unit of $\mathrm{PBI})$, i.e. the wt. ratios of $[\mathrm{LiCl}] /[\mathrm{PBI}]$ were $0.50,0.69,0.83,1.00,1.10,1.25,1.50,2.00$, respectively.

\subsection{Characterizations of $2 \mathrm{mg} / \mathrm{ml} \mathrm{PBI} / \mathrm{DMAc} / \mathrm{LiCl}$ Solutions}

The characterizations of $2.0 \mathrm{mg} / \mathrm{ml} \mathrm{PBI}$ in DMAc solutions with various concentrations of $\mathrm{LiCl}$ were performed at $25^{\circ} \mathrm{C}$. (1) The dynamic shear viscosities of solutions were measured using a capillary VE viscoelastic analyzer (Vilastic Co, Inc, Austin, TX) with a capillary inner diameter of $0.0513 \mathrm{~cm}$ and a capillary length of $6.115 \mathrm{~cm}$;
(2) The hydrodynamic radii $\left(R_{G}\right)$ of $2 \mathrm{mg} / \mathrm{ml}$ PBI in DMAc solutions mixed with various concentrations of $\mathrm{LiCl}$ were obtained from dynamic light scattering (DLS) measurements at a scattering angle of $\theta=60^{\circ}$ using a BI-9000 correlator (Brookhaven Co., Inc, USA). The incident light source was a He-Ne ion laser (Spectra Physics Inc) with a wavelength of $\lambda=633 \mathrm{~nm}$ and was operated at $20 \mathrm{~mW}$. The PBI solutions were filtered through a Millipore filter (FHLP 02500, pore size $1.0 \mu \mathrm{m}$ ) before $D L S$ measurements were carried out; (3) The Zeta-potential of $2 \mathrm{mg} / \mathrm{ml} \mathrm{PBI}$ in DMAc solutions mixed with various concentrations of $\mathrm{LiCl}$ were analyzed using a Zeta-potential analyzer (Brookhaven Co).

\subsection{Preparations of $\mathrm{PBI} / \mathrm{H}_{3} \mathrm{PO}_{4}$ Membranes}

A $2 \mathrm{wt} \%$ of $\mathrm{PBI} / \mathrm{LiCl} / \mathrm{DMAc}$ solution with $[\mathrm{LiCl}] /[\mathrm{BI}]$ molar ratios of $8.0(\mathrm{LiCl} / \mathrm{PBI}=1.10$ in wt. ratio) was prepared under nitrogen atmosphere at $150^{\circ} \mathrm{C}$. The DMAc solvent was then evaporated from the solution at $80^{\circ} \mathrm{C}$ under vacuum to obtain a solution with a PBI content of around 5 $w t \%$. The PBI solution was coated on a glass plate using a film applicator with a gate thickness of $140 \mu \mathrm{m}$. The glass plate with a thin film of PBI solution was heated at $80^{\circ} \mathrm{C}$ for $1 \mathrm{~h}$ and then $120^{\circ} \mathrm{C}$ for $5 \mathrm{~h}$ under vacuum to remove DMAc solvent. The PBI membrane was then immersed in distilled water for 3 days and the water was changed each day to remove LiCl. Finally, the PBI membrane was immersed in $85 \mathrm{wt} \%$ phosphoric acid solution for 3 days. The final thickness of $\mathrm{PBI} / \mathrm{H}_{3} \mathrm{PO}_{4}$ membranes were around 94 98 $\mu \mathrm{m}$.

\subsection{Preparations of $\mathrm{PBI} / \mathrm{H}_{3} \mathrm{PO}_{4}$-PTFE Composite Membranes}

Before porous PTFE thin film was impregnated in a PBI solution, PTFE thin film was treated with a $0.7 \mathrm{wt} \%$ Nafion solution. And, then the PTFE thin film coated with a thin layer of Nafion on the surfaces of PTFE fibers was impregnated in a PBI solution to prepare a $\mathrm{PBI} / \mathrm{H}_{3} \mathrm{PO}_{4}-\mathrm{PTFE}$ composite membrane. Herein Nafion is used as a coupling agent between PTFE and PBI, the perfluorocarbon backbone of Nafion is compatible with PTFE and the vinyl ether sulfonic acid side chain of Nafion is compatible with PBI. The procedures for preparing a PBI/PTFE composite membrane are as following:

(2.5-a) The solvent of as received $5 \mathrm{wt} \%$ Nafion solution $(E W=1100, \mathrm{Du}$ Pont $\mathrm{Co})$ was evaporated under vacuum at $60^{\circ} \mathrm{C}$ and the residual solid Nafion resin was mixed with $2-$ propanol/ water (4/1 wt ratio) mixture solvent to a solution containing $0.7 \mathrm{wt} \%$ of Nafion. Porous PTFE film (thickness $16 \pm 2 \mu \mathrm{m}$, pore seizes $0.5 \pm 0.1 \mu \mathrm{m}$, and porosity $85 \pm 5 \%$, YuMing-Tai Chem Co, Taiwan) was mounted on a $12 \times 12 \mathrm{~cm}^{2}$ steel frames and boiled in acetone at $55^{\circ} \mathrm{C}$ for $1 \mathrm{hr}$. This pretreated PTFE membrane was then impregnated with a 0.7 $\mathrm{wt} \%$ Nafion solution for $24 \mathrm{hr}$. These impregnated membranes were then annealed at $130^{\circ} \mathrm{C}$ for $1 \mathrm{hr}$. After annealing, the membrane was then swollen with distilled water for $24 \mathrm{hr}$. Thus the porous PTFE membrane was coated with a thin film of Nafion. (2.5-b) The porous PTFE membrane coated with a thin film of Nafion was impregnated in a $\mathrm{PBI} / \mathrm{LiCl} / \mathrm{DMAc}(4.5 / 5.0 / 100$ in wt ratio, $[\mathrm{LiCl}] /[\mathrm{BI}]=1.1 / 1.0 \mathrm{in} \mathrm{mol}$ ratio) solution for $5 \mathrm{~min}$, the membrane was then heated at $80^{\circ} \mathrm{C}$ for $30 \mathrm{~min}$ and then $120^{\circ} \mathrm{C}$ for $30 \mathrm{~min}$ under vacuum. The process of membrane impregnation in $\mathrm{PBI} / \mathrm{LiCl} / \mathrm{DMAc}$ solution and annealing was 
repeated for 3 5 times to obtain a composite membrane with a desired film thickness. The PBI/PTFE composite membrane was then immersed in distilled water for 3 days and the water was changed each day to remove $\mathrm{LiCl}$. Finally, the PBI/PTFE composite membrane was immersed in 85 $\mathrm{wt} \%$ phosphoric acid for 3 days to obtain $\mathrm{PBI} / \mathrm{H}_{3} \mathrm{PO}_{4}-\mathrm{PTFE}$ composite membrane.

\subsection{Characterizations of $\mathrm{PBI} / \mathrm{H}_{3} \mathrm{PO}_{4}$-PTFE Composite Membranes}

The morphology of membranes was investigated using a scanning electron microscope (SEM, model JSM-5600, Jeol Co., Japan). The sample surface was coated with gold powder under vacuum before SEM observation was performed. The membrane acid-doping contents were determined by weighing the membranes before and after doping phosphoric acid. In order to avoid the deviation from moisture contents, before weighing, the membranes were dried by evaporating the water at $110^{\circ} \mathrm{C}$ under vacuum for more than $10 \mathrm{~h}$ until an unchanged weight was obtained. The ionic conductivities $(\sigma)$ of membranes were measured by using a four-probe cell. The measurements were performed at temperatures of $150^{\circ} \mathrm{C}$ with a relative humidity of $18+2 \%$ by ac impedance spectroscopy using a Solartron 1260 gain phase analyzer interfaced to a Solartron 1480 multi-meter.

\subsection{PEMFC Single Cell Test}

A PBI membrane and a $\mathrm{PBI} / \mathrm{H}_{3} \mathrm{PO}_{4}$-PTFE composite membrane prepared according to the procedure described in sec. 2.4 were used to prepare MEAs. The catalyst was Pt-C (carbon supported platinum, E-TEK, $40 \mathrm{wt} \% \mathrm{Pt}$ ) and the $\mathrm{Pt}$ loadings of anode and cathode were $0.5 \mathrm{mg} / \mathrm{cm}^{2} . \mathrm{Pt}-\mathrm{C} / \mathrm{PBI} /$ $\mathrm{LiCl} /$ DMAc $(3.5 / 1 / 0.5 / 49$ by wt) catalyst solution was prepared by ultrasonic disturbing for $5 \mathrm{hr}$. In catalyst ink solution, $\mathrm{LiCl}$ was a stabilizer of $\mathrm{PBI} / \mathrm{DMAC}$ solution. The catalyst ink was brushed onto a carbon cloth (E-TEK, HT $2500-\mathrm{W})$, dried at $110^{\circ} \mathrm{C}$ in a conventional oven to calculate catalyst loading. The catalyst coated carbon cloths were immersed in deionized water for $24 \mathrm{~h}$ to remove $\mathrm{LiCl}$. They were then doped with phosphoric acids by dipping in $10 \%$ $\mathrm{H}_{3} \mathrm{PO}_{4}$ solution for $24 \mathrm{~h}$ and dried in oven at $110^{\circ} \mathrm{C}$. The membrane was sandwiched between two carbon cloths coated with a catalyst layer and pressed at $150^{\circ} \mathrm{C}$ with a pressure of $50 \mathrm{~kg} / \mathrm{cm}^{2}$ for $5 \mathrm{~min}$ to obtain a MEA. The unit cell performances were tested at $150^{\circ} \mathrm{C}$ using a FC5100 fuel cell testing system (CHINO Inc., Japan). The area of testing fixture was $5 \times 5 \mathrm{~cm}^{2}$ and the anode $\mathrm{H}_{2}$ cathode $\mathrm{O}_{2}$ input flow rates were $300 \mathrm{ml} / \mathrm{min}$. Both $\mathrm{H}_{2}$ and $\mathrm{O}_{2}$ flows were unhumidified.

\section{RESULTS AND DISCUSSION}

In general, PBI membranes are not dissolved in most of solvents, due to its strong inter-polymer hydrogen bonding between $-\mathrm{NH}$ and $-\mathrm{N}=\mathrm{C}$ - groups (see the chemical structure of PBI shown in Fig. 1). PBI can be dissolved in DMAc mixed with $\mathrm{LiCl}$. By mixing $\mathrm{LiCl}$ into PBI/DMAc solution, the hydrogen bonds formed from $-\mathrm{NH} \ldots-\mathrm{N}=\mathrm{C}$ - groups can be dissociated. Thus the mobility, zeta potential and particle sizes (i.e. hydrodynamic radius $R_{h}$ ) of $\mathrm{PBI}$ in DMAc/ $\mathrm{LiCl}$ solutions and viscosities of $\mathrm{PBI} / \mathrm{DMAc} / \mathrm{LiCl}$ solutions vary with $\mathrm{LiCl}$ concentration in the solutions.

\subsection{Zeta Potential for Dilute PBI/DMAc/LiCl Solutions}

Zeta potential measurement is a reliable method to investigate particles stability of the colloidal system. Table $\mathbf{1}$ shows the mobility and Zeta potential of PBI in $2 \mathrm{mg} / \mathrm{ml}$ $\mathrm{PBI} / \mathrm{LiCl} / \mathrm{DMAc}$ solutions with various molar ratios of $[\mathrm{LiCl}] /[\mathrm{BI}]$. The data showed the mobility and Zeta potential of PBI in the solution increased with increasing $\mathrm{LiCl}$ concentration and reached a maximum mobility and a maximum Zeta potential as the molar ratio of $[\mathrm{LiCl}] /[\mathrm{BI}]$ was at 8.0 . When the molar ratio of $[\mathrm{LiCl}] /[\mathrm{BI}]$ was increased above 8.00 , the mobility and Zeta potential of PBI solution decreased with increasing molar ratio of $[\mathrm{LiCl}] /[\mathrm{BI}]$.

Table 1. Mobility and Zeta Potential Values of PBI/DMAc/ LiCl Solutions with Various [LiCl]/[BI] Molar Ratios

\begin{tabular}{|c|c|c|}
\hline $\begin{array}{c}{[\mathbf{L i C l}] /[\mathrm{BI}]} \\
\text { Molar Ratio }\end{array}$ & $\begin{array}{c}\text { Mobility*10 } \\
\left(\mathbf{m}^{\mathbf{2}} \mathbf{V}^{-\mathbf{- 1}} \mathbf{s}^{-\mathbf{1}}\right)\end{array}$ & $\begin{array}{c}\text { Zeta Potential } \\
(\mathbf{m V})\end{array}$ \\
\hline \hline 3.62 & 0.75 & -22.97 \\
\hline 5.00 & 0.96 & -29.25 \\
\hline 7.26 & 1.06 & -32.20 \\
\hline 8.00 & 1.24 & -37.66 \\
\hline 9.07 & 1.15 & -35.10 \\
\hline 10.88 & 1.12 & -34.17 \\
\hline 14.51 & 1.09 & -33.28 \\
\hline
\end{tabular}

\subsection{Dynamic Shear Viscosities of PBI/DMAc/LiCl Solutions}

The dynamic shear viscosities of $2.0 \mathrm{mg} / \mathrm{ml}$ PBI in DMAc solutions mixed with various concentrations of $\mathrm{LiCl}$ were measured using a Vilastic VE viscoelastic analyzer. The dynamic shear viscosity $\eta(\omega)$ data of PBI solutions were plotted against shear frequency $\omega$ and are shown in Fig. (2). All the $\eta(\omega)$ data, except the solution with $[\mathrm{LiCl}] /[\mathrm{BI}]=8 / 1$ mol ratio, show a shear thinning behavior at $\omega<\omega_{\text {onset }}$ (i.e. $\eta(\omega)$ decreases with increasing $\omega)$ and a shear thickening behavior at $\omega>\omega_{\text {onset }}$ (i.e. $\eta(\omega)$ increases with increasing $\omega$ ). The PBI solution with $[\mathrm{LiCl}] /[\mathrm{BI}]=8 / 1 \mathrm{~mol}$ ratio shows a Newtonian solution at $\omega<\omega_{\text {onset }}$ (i.e. $\eta(\omega)$ does not change with increasing $\omega$ ) and a shear thickening behavior at $\omega>$ $\omega_{\text {onset }}$ (i.e. $\eta(\omega)$ increases with increasing $\omega$ ). Where $\omega_{\text {onset }}$ is the critical $\omega$ at which the solution viscosity starts to increase as the $\omega$ is increased from a low frequency to a high frequency. The shear thinning and thickening behavior of polymer solutions had been reported in literatures [23-25]. Most of researchers attributed the shear thinning of a polymer solution to the dissociation of polymer aggregates by the shear force. At high shear frequencies $\left(\omega>\omega_{\text {onset }}=\right.$ $10 \sim 30 \mathrm{rad} / \mathrm{sec}$ in Fig. 2), the polymer chains were highly extended by the shear force. The extension of polymer chains increases the inter-polymer contact frequency. The shear thickening behavior of a solution at a high shear frequency can be attributed to the inter-polymer association of these extended polymer chains [23-25]. The $\eta(\omega)$ data at $\omega=1.0 \mathrm{rad} / \mathrm{sec}$ (the frequency in the shear thinning region) and the $\omega_{\text {onset }}$ data for $\mathrm{PBI} / \mathrm{DMAC} / \mathrm{LiCl}$ solutions with various molar ratios of $[\mathrm{LiCl}] /[\mathrm{BI}]$ are listed in Table 2. 
Table 2 shows that $\eta(\omega=1.0 \mathrm{rad} / \mathrm{sec})$ and $\omega_{\text {onset }}$ decrease when the $[\mathrm{LiCl}] /[\mathrm{BI}]$ molar ratio decreases from 3.63 to 8.00 . Then, $\eta(\omega=1.0 \mathrm{rad} / \mathrm{sec})$ and $\omega_{\text {onset }}$ increase when the $[\mathrm{LiCl}] /[\mathrm{BI}]$ molar ratio increases from 8.00 to 14.51 . The data of Table 2 reveal that there is a lowest viscosity and a lowest $\omega_{\text {onset }}$ as the $[\mathrm{LiCl}] /[\mathrm{BI}]$ molar ratio in $\mathrm{PBI} / \mathrm{DMAc} / \mathrm{LiCl}$ solutions is around 8.00. The $\eta(\omega=1.0$ $\mathrm{rad} / \mathrm{sec}$ ) data suggest there are aggregations of PBI molecules in DMAc solutions at low shear frequencies when $\mathrm{LiCl}$ is not mixed into the solution. The mixing of $\mathrm{LiCl}$ into $\mathrm{PBI} / \mathrm{DMAc}$ solution causes dissociation of PBI aggregates via the $\left[>\mathrm{N} \ldots \mathrm{H}^{\delta^{+}} \ldots \mathrm{Cl}^{\delta-} \ldots \mathrm{N}<\right]$ interactions among the imidazole groups of $\mathrm{PBI}$ polymers as molar ratio of $[\mathrm{LiCl}] /[\mathrm{BI}]$ was increased from 0.0 to 8.00 . As molar ratio of $[\mathrm{LiCl}] /[\mathrm{BI}]$ was increased from 8.00 to 10.88 , the excess contents of $\mathrm{Li}^{+}$and $\mathrm{Cl}^{-}$ions results in hydrophobicity of PBI molecules in the DMAc solutions. Thus inter-polymer hydrophobic aggregations increased with increasing $\mathrm{LiCl}$ concentration as molar ratio of $[\mathrm{LiCl}] /[\mathrm{BI}]$ was increased from 8.00 to 10.88 . Table 2 also shows the $\omega_{\text {onset }}$ strongly depends on the aggregation behavior PBI molecules in the solution. The higher degree of PBI aggregations in a solution (i.e. the higher viscosity of a PBI solution) leads to a higher shear frequency (i.e. $\omega_{\text {onset }}$ ) or shear force to dissociate the PBI molecular chains from the aggregates and to form extended polymer chains. Further discussion of the influence of $\mathrm{LiCl}$ concentration on PBI aggregations in DMAc will be shown in section 3.4 .

Table 2. $\eta(\omega=1.0 \mathrm{rad} / \mathrm{sec})$ and $\omega_{\text {onset }}$ Data of $2 \mathrm{mg} / \mathrm{ml}$ PBI/DMAc/LiCl Solutions

\begin{tabular}{|c|c|c|}
\hline$[\mathbf{L i C l}] /[\mathbf{B I}]$ (Mole Ratio) & $\boldsymbol{\eta}(\boldsymbol{\omega}=\mathbf{1 . 0} \mathbf{~ r a d} / \mathbf{s e c})$ & $\boldsymbol{\omega}_{\text {onset }}(\mathbf{r a d} / \mathbf{s e c})$ \\
\hline \hline 3.62 & 0.033 & 34.0 \\
\hline 5.00 & 0.016 & 11.5 \\
\hline 7.26 & 0.015 & 10.3 \\
\hline 8.00 & 0.014 & 9.0 \\
\hline 9.07 & 0.018 & 9.7 \\
\hline 10.88 & 0.021 & 12.0 \\
\hline 14.51 & 0.023 & 12.3 \\
\hline
\end{tabular}

\subsection{Hydrodynamic Radius Distributions of PBI in 2.0 mg/ml PBI/DMAc/LiCl Solutions}

Fig. (3) shows the hydrodynamic radius $R_{h}$ distributions for $2 \mathrm{mg} / \mathrm{ml} \mathrm{PBI}$ in $\mathrm{DMAc} / \mathrm{LiCl}$ solutions with various $[\mathrm{LiCl}] /[\mathrm{BI}]$ molar ratios. The $R_{h}$ data were obtained from $D L S$ measurements at a scattering angle $\theta=60^{\circ}$. These data show the PBI has average $\left\langle R_{h}>\right.$ value around $30 \sim 70 \mathrm{~nm}$ in the solutions. Fig. (3) shows that $\left\langle R_{h}>\right.$ decreased from $\sim 70$ $\mathrm{nm}$ to $\sim 30 \mathrm{~nm}$ as $[\mathrm{LiCl}] /[\mathrm{BI}]$ molar ratio was increased from 3.63 to 8.00 , then $\left\langle R_{h}>\right.$ increased from $\sim 30 \mathrm{~nm}$ to $\sim 73 \mathrm{~nm}$ when the $[\mathrm{LiCl}] /[\mathrm{BI}]$ molar ratio was increased from 8.00 to 14.51. There is a lowest $\left\langle R_{h}>\right.$ as the $[\mathrm{LiCl}] /[\mathrm{BI}]$ molar ratio is around $\sim 8.00$. This behavior is similar to the $[\mathrm{LiCl}] /[\mathrm{BI}]$ molar ratio dependencies of shear viscosity $\eta(\omega=1.0$ $\mathrm{rad} / \mathrm{sec}$ ) data (Table 2) and mobility and zeta potential data (Table 1).

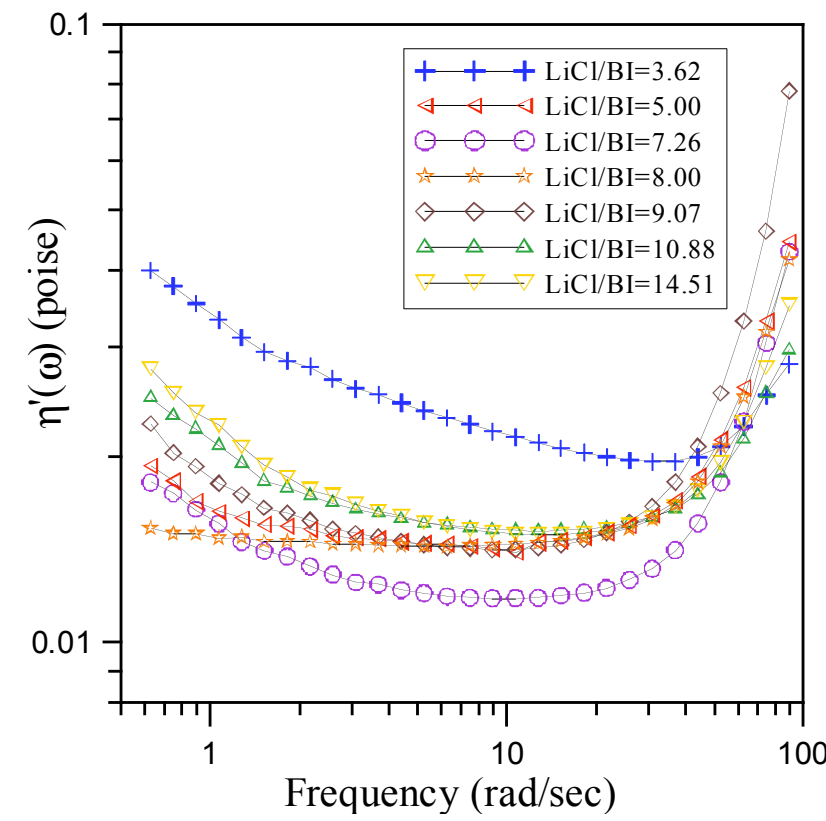

Fig. (2). $\eta(\omega) v s$ frequency $\omega$ for $\mathrm{PBI} / \mathrm{DMAc} / \mathrm{LiCl}$ solutions with various $[\mathrm{LiCl}] /[\mathrm{BI}]$ molar ratios, where $[\mathrm{BI}]$ is a repeat unit of $\mathrm{PBI}$. The PBI concentration is $2 \mathrm{mg} / \mathrm{ml}$. [LiCl]/[BI] molar ratio: $(+) 3.62$;

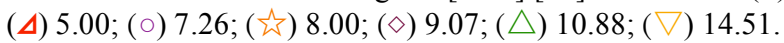

\subsection{Discussion of Dilute PBI/DMAc/LiCl Solutions Properties}

From the results of Tables $\mathbf{1}$ and 2, and Figs. (2, 3), we found that there were maxima values of mobility and zeta potential and minima values of solution viscosity and $R_{h}$ as the $[\mathrm{LiCl}] /[\mathrm{BI}]$ molar ratio of $\mathrm{PBI} / \mathrm{DMAc} / \mathrm{LiCl}$ solutions was around $\sim 8.0$. These results suggest that there are interpolymer associations through hydrogen bonding of $-\mathrm{N}-\mathrm{H}$ with $-\mathrm{N}=\mathrm{C}$ - groups of imidazole functional groups in the $\mathrm{PBI} / \mathrm{DMAc}$ solutions without mixing with $\mathrm{LiCl}$. The mixing of $\mathrm{LiCl}$ into $\mathrm{PBI} / \mathrm{DMAc}$ solutions results in the bonding of $\mathrm{Li}^{+}$ions on the imidazole group which causes dissociation of inter-polymer hydrogen bonds between $-\mathrm{N}-\mathrm{H}$ and-N=Cgroups as the $[\mathrm{LiCl}] /[\mathrm{BI}]$ molar ratio of $\mathrm{PBI} / \mathrm{DMAc} / \mathrm{LiCl}$ solution was increased from 0.0 to 8.0 . The bonding of $\mathrm{Li}^{+}$ ions on the imidazole groups of PBI results in the increase in the zeta potential. The dissociation of inter-polymer hydrogen bonds between $-\mathrm{N}-\mathrm{H}$ and $-\mathrm{N}=\mathrm{C}$ - groups results in the increase of polymer mobility and the decreases of solution viscosity and polymer particles sizes $R_{h}$. When the $[\mathrm{LiCl}] /[\mathrm{BI}]$ molar ratio of $\mathrm{PBI} / \mathrm{DMAc}$ solutions is higher than 8.0, further mixing of $\mathrm{LiCl}$ into $\mathrm{PBI} / \mathrm{DMAc}$ solution results in hydrophobic associations of PBI molecules in DMAc. Thus zeta potential and polymer mobility decrease as the $[\mathrm{LiCl}] /[\mathrm{BI}]$ molar ratio in the solutions is increased above 8.0 (Table 1). The inter-polymer association also causes increases of solution viscosity (Table 2) and PBI aggregated particles sizes (Fig. 3) as the $[\mathrm{LiCl}] /[\mathrm{BI}]$ molar ratio is higher than 8.0.

\subsection{Characterizations of $\mathrm{PBI} / \mathrm{H}_{3} \mathrm{PO}_{4}$ Membrane and $\mathrm{PBI} / \mathrm{H}_{3} \mathrm{PO}_{4}$-PTFE Composite Membrane}

The porous PTFE used for PBI/PTFE composite membrane preparation had an average pore size of $0.5 \pm 0.1$ $\mu \mathrm{m}$ and porosity of $85 \pm 5 \%$. The fabrication of $\mathrm{PBI} / \mathrm{DMAc} /$ 


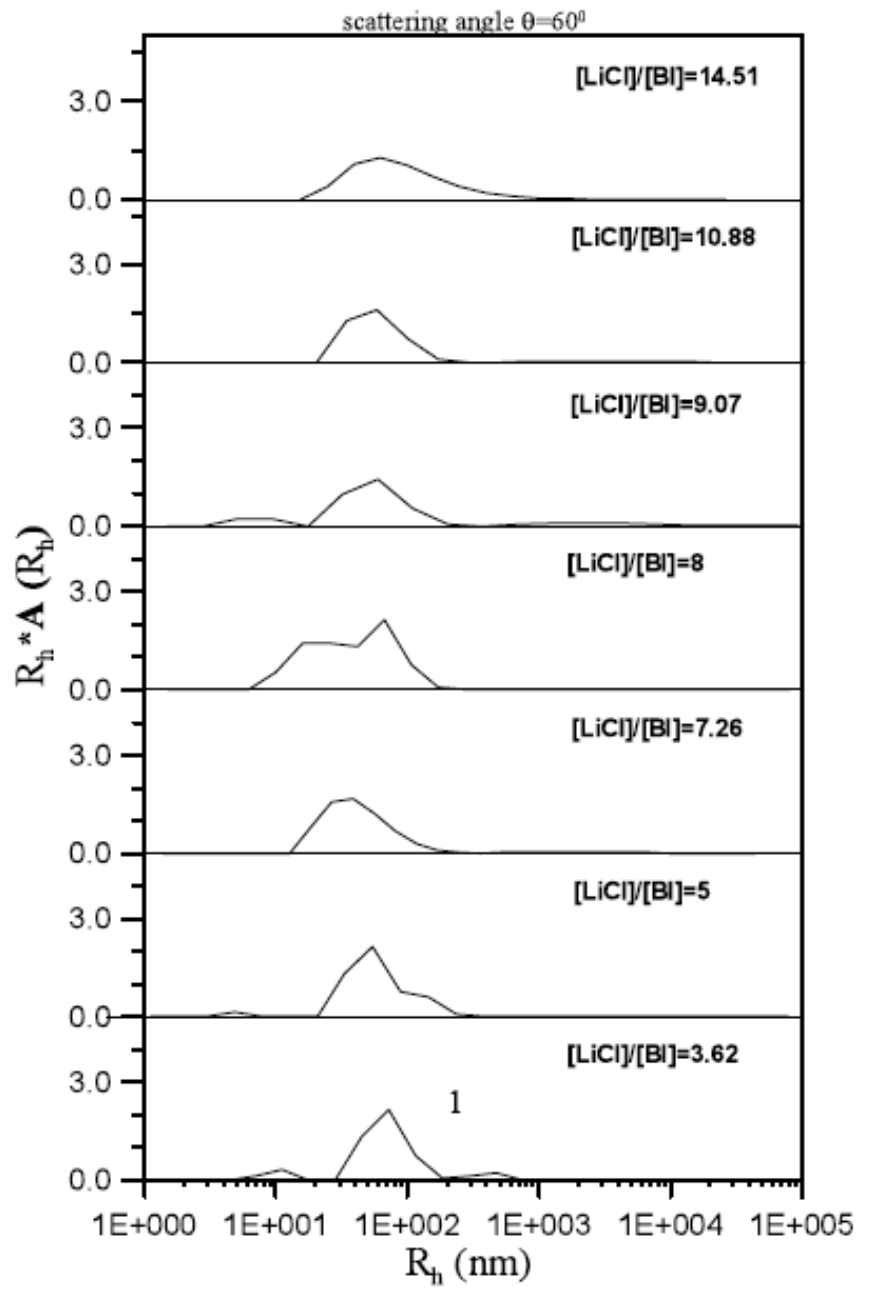

Fig. (3). DLS $R_{h}$ distributions of $\mathrm{PBI} / \mathrm{DMAc} / \mathrm{LiCl}$ solutions with various $[\mathrm{LiCl}] /[\mathrm{BI}]$ molar ratios (numeric values indicated in figure), $[\mathrm{PBI}]=2 \mathrm{mg} / \mathrm{ml}$, scattering angle $\theta=60^{\circ}$. $[\mathrm{LiCl}] /[\mathrm{BI}]=$ $14.51,10.88,9.07,8.00,7.26,5.00,3.62$ in molar ratio (from top to bottom)

$\mathrm{LiCl}$ solutions on porous PTFE thin films and the properties of PBI/PTFE composite membranes strongly depend on the solutions properties of PBI/DMAc. As shown in Fig. (2), the PBI particles sizes distribute from $20 \mathrm{~nm}$ to $800 \mathrm{~nm}$ in DMAc/ $\mathrm{LiCl}$ solutions. It is obvious the solution with lower polymer aggregations should be more suitable for the impregnation PBI molecules into the porous PTFE film. Because of lowest solution viscosity, lowest PBI particles sizes, and highest polymer mobility, the $\mathrm{PBI} / \mathrm{DMAc} / \mathrm{LiCl}$ solution with a $[\mathrm{LiCl}] /[\mathrm{BI}]$ molar ratio of 8.0 was used for preparing $\mathrm{PBI} / \mathrm{PTFE}$ composite membranes in the present work. Fig. (4a, b) show the SEM micrographs of the surfaces of porous PTFE thin film and PBI/PTFE composite membrane without doping phosphoric acid. The SEM micrograph of Fig. (4a) shows that there are fibers with knots visible in the membrane and among the fibers and knots there are micro pores in the PTFE film. Fig. (4b) shows the micro pores of the PTFE film had been filled and completely covered with PBI. The membrane thickness $(l)$, phosphoric acid doping level $\left(\left[\mathrm{H}_{3} \mathrm{PO}_{4}\right] /[\mathrm{BI}]\right.$ in molar ratio), proton conductivity $(\sigma)$, and resistance per unit area $(l / \sigma)$ of pure PBI membrane and the PBI/PTFE membrane after doping with phosphoric acid are shown in Table $\mathbf{3}$. Table $\mathbf{3}$ shows that though the $\sigma$ of $\mathrm{PBI} / \mathrm{H}_{3} \mathrm{PO}_{4}$-PTFE is lower than that of $\mathrm{PBI} / \mathrm{H}_{3} \mathrm{PO}_{4}$, the $\mathrm{PBI} / \mathrm{H}_{3} \mathrm{PO}_{4}$-PTFE has a lower $l / \sigma$ than $\mathrm{PBI} / \mathrm{H}_{3} \mathrm{PO}_{4}$, due to the lower $l$ of $\mathrm{PBI} / \mathrm{H}_{3} \mathrm{PO}_{4}-\mathrm{PTFE}$ than $\mathrm{PBI} / \mathrm{H}_{3} \mathrm{PO}_{4}$.

(a)

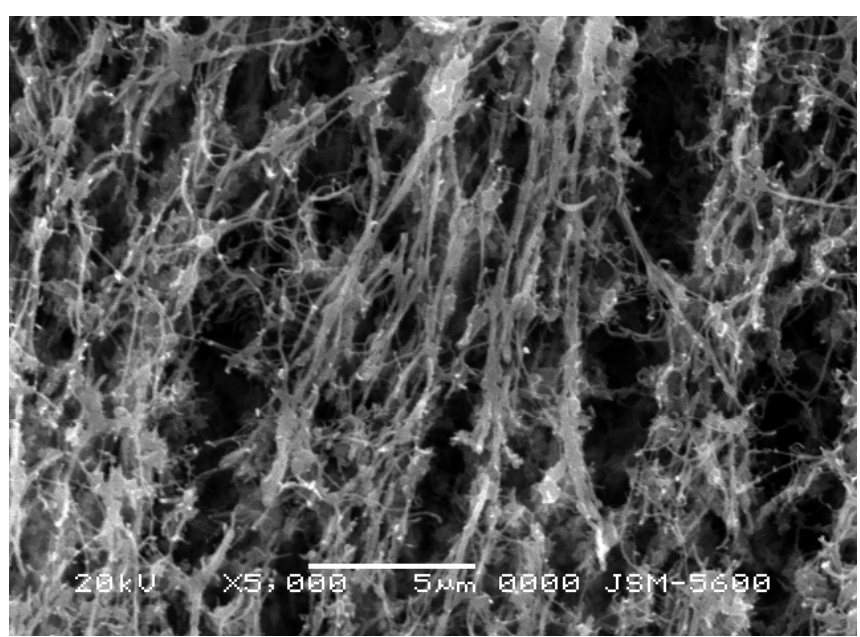

(b)

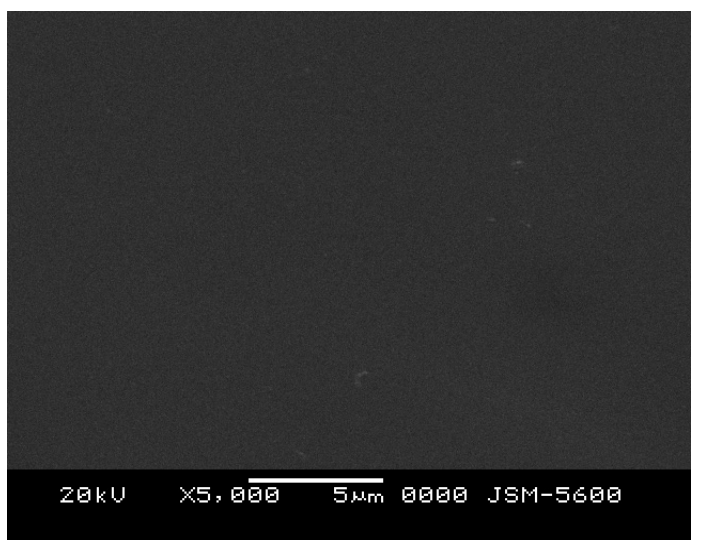

Fig. (4). SEM micrographs (x5000). (a) porous PTFE film; (b) PBI/PTFE composite membrane.

\subsection{High Temperature PEMFC Unit Cell Performance Test}

For the purpose of a reference, we also prepared a pure PBI membrane by solution casting from a PBI/DMAc/LiCl solution with a $[\mathrm{LiCl}] /[\mathrm{BI}]$ molar ratio of 8.0 . The

Table 3. Properties of $\mathrm{PBI} / \mathrm{H}_{3} \mathrm{PO}_{4}$ and $\mathrm{PBI} / \mathrm{H}_{3} \mathrm{PO}_{4}$-PTFE Membrane

\begin{tabular}{|c|c|c|c|c|}
\hline Membrane & Thickness $\boldsymbol{l}(\boldsymbol{\mu} \mathbf{m})$ & {$\left[\mathbf{H}_{3} \mathbf{P O} \mathbf{O}_{4}\right] /[\mathbf{B I}](\mathbf{m o l}$ Ratio) } & *Conductivity $\boldsymbol{\sigma}\left(\mathbf{1 0} \mathbf{s}^{-3} \mathbf{S} / \mathbf{c m}\right)$ & $\boldsymbol{l} / \boldsymbol{\sigma}\left(\mathbf{c m}^{2} / \mathbf{S}\right)$ \\
\hline \hline $\mathrm{PBI} / \mathrm{H}_{3} \mathrm{PO}_{4}$ & 98 & 4.11 & 17.4 & 0.56 \\
\hline $\mathrm{PBI} / \mathrm{H}_{3} \mathrm{PO}_{4}-\mathrm{PTFE}$ & 22 & 3.73 & 4.76 & 0.46 \\
\hline
\end{tabular}


$\mathrm{PBI} / \mathrm{H}_{3} \mathrm{PO}_{4}$ membrane and $\mathrm{PBI} / \mathrm{H}_{3} \mathrm{PO}_{4}$-PTFE composite membrane were used to prepared MEAs. The PEMFC single cells performance tests were carried out at $150^{\circ} \mathrm{C}$ under $\mathrm{H}_{2}$ and $\mathrm{O}_{2}$ flow rates of $300 \mathrm{ml} / \mathrm{min}$. Fig. (5) shows the cell potential $V$ versus current density $i$ curves of these two MEAs. Fig. (5) shows the voltages of single fuel cells fall as current density increases. One of the reasons for the falling down of the voltage with increasing current density is the so called "ohmic loss" which comes from the resistance to the flow of ions through the polymer electrolyte membrane [2]. It is found that MEA prepared from $\mathrm{PBI} / \mathrm{H}_{3} \mathrm{PO}_{4}-\mathrm{PTFE}$ composite membrane had a lower negative slope of $V$ versus $i$ at $i \geq 200 \mathrm{~mA} / \mathrm{cm}^{2}$ and thus a lower "ohmic loss" and a better fuel cell performance than $\mathrm{PBI} / \mathrm{H}_{3} \mathrm{PO}_{4}$ membrane. The better fuel cell performance of $\mathrm{PBI} / \mathrm{H}_{3} \mathrm{PO}_{4}-\mathrm{PTFE}$ than $\mathrm{PBI} / \mathrm{H}_{3} \mathrm{PO}_{4}$ can be attributed to the thinner thickness $l$ and a lower resistance (i.e. $l / \sigma$ ) of $\mathrm{PBI} / \mathrm{H}_{3} \mathrm{PO}_{4}-\mathrm{PTFE}$ than $\mathrm{PBI} / \mathrm{H}_{3} \mathrm{PO}_{4}$.

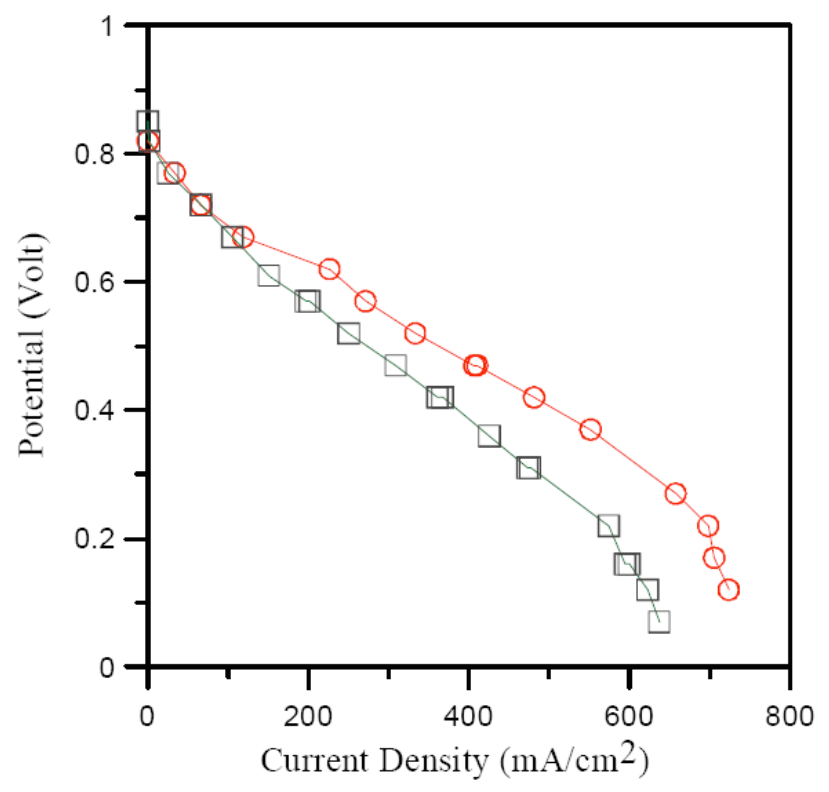

Fig. (5). PEMFC single cell voltage versus current density of MEA prepared from $\mathrm{PBI} / \mathrm{H}_{3} \mathrm{PO}_{4}(98 \mu \mathrm{m})$ and $\mathrm{PBI} / \mathrm{H}_{3} \mathrm{PO}_{4}$-PTFE $(22 \mu \mathrm{m})$ and operated at $150^{\circ} \mathrm{C}$ with unhumidified $\mathrm{H}_{2} / \mathrm{O}_{2}$ flow rates of 300 $\mathrm{ml} / \mathrm{min}$. (口) $\mathrm{PBI} / \mathrm{H}_{3} \mathrm{PO}_{4}$; ( ( ) $\mathrm{PBI} / \mathrm{H}_{3} \mathrm{PO}_{4}$-PTFE.

\section{CONCLUSIONS}

Because of strong inter-polymer hydrogen bond, PBI is hard to be dissolved in solvents. By mixing $\mathrm{LiCl}$ into PBI/DMAc solutions, PBI can be dissolved and dispersed in DMAc solutions. In this study, we show the $2 \mathrm{mg} / \mathrm{ml}$ dilute $\mathrm{PBI} / \mathrm{DMAc} / \mathrm{LiCl}$ solutions has a lowest solution viscosity and smallest PBI aggregate particles sizes when the molar ratio of $[\mathrm{LiCl}] /[\mathrm{BI}]$ molar ratio is around $\sim 8.0$ in the $\mathrm{PBI}$ solution. The $\mathrm{PBI} / \mathrm{DMAc} / \mathrm{LiCl}$ solution with a $[\mathrm{LiCl}] /[\mathrm{BI}]$ molar ratio of 8.0 was used to prepare PBI membrane and PBI/PTFE composite membrane. Owing to the high mechanical strength of porous PTFE, the thickness of $\mathrm{PBI} / \mathrm{H}_{3} \mathrm{PO}_{4}$-PTFE composite membrane is allowed to be lower than that of pure $\mathrm{PBI} / \mathrm{H}_{3} \mathrm{PO}_{4}$ membrane. The lower membrane thickness of $\mathrm{PBI} / \mathrm{H}_{3} \mathrm{PO}_{4}$-PTFE than $\mathrm{PBI} / \mathrm{H}_{3} \mathrm{PO}_{4}$ results in a lower $l / \sigma$ of $\mathrm{PBI} / \mathrm{H}_{3} \mathrm{PO}_{4}$-PTFE. Thus the MEA prepared from $\mathrm{PBI} / \mathrm{H}_{3} \mathrm{PO}_{4}-\mathrm{PTFE}$ has a better fuel cell performance than that prepared from $\mathrm{PBI} / \mathrm{H}_{3} \mathrm{PO}_{4}$.

\section{ACKNOWLEDGEMENTS}

The authors would like to thank for the financial support by Bureau of Energy, Ministry of Economy Affair of ROC through grant 97-D0137-4.

\section{REFERENCES}

[1] Barbir F. PEM fuel cells- theory and practice, Elsevier Academic Press: Burling, MA, USA, 2005.

[2] Larminie, J.; Dicks, A. Fuel cell system explained. John Wiley \& Sons: Chichester, West Sussex, England, 2000.

[3] Kordesch, K.; Simader, G.. Fuel cells and their applications. VCH Publishers: New York, 1996, pp. 79.

[4] Mehta, V.; Cooper, J.S. Review and analysis of PEM fuel cell design and manufacturing. J. Power Sourc., 2003, 114, 32-53.

[5] Wainright, J.S.; Wang, J.T.; Weng, D.; Savinell, R.F.; Litt, M. Acid doped polybenzimidazoles: A new polymer electrolyte. $J$. Electrochem. Soc., 1995, 142(7), L121-L123.

[6] Wang, J.T.; Savinell, R.F.; Wainright, J.; Litt, M.; Yu, H. A $\mathrm{H}_{2} / \mathrm{O}_{2}$ fuel cell using acid doped polybenzimidazole as polymer electrolyte. Electrochem. Acta, 1996, 41(2), 193-197.

[7] Wang, J.T.; Wasmus, S.; Savinell, R.F. Thermal stability of proton conducting acid doped polybenzimidazole in simulated fuel cell environments. J. Electrochem. Soc., 1996, 143(4), 1225-1239.

[8] Fontanella, J.J.; Wintersgill, M.C.; Wainright, J.S.; Savinell, R.F.; Litt, M. High pressure electrical conductivity studies of acid doped polybenzimidazole. Electrochim. Acta, 1998, 43, 1289-1294.

[9] Ma, Y.L.; Wainright J.S.; Litt, M.; Savinell, R.F. Conductivity of PBI membranes for high-temperature polymer electrolyte fuel cells. J. Electrochem. Soc., 2004, 151(1), A8-A16.

[10] Li, Q.; Hiuler, H.A.; Bjerrum ,N.J. Phosphoric acid doped polybenzimidazole membranes: physiochemical characterization and fuel cell applications. J. Appl. Electrochem., 2001, 31, 773779 .

[11] Liu, C.; Martin, C.R. Ion-transporting composite membranes. II. Ion transport mechanism in Nafion-impregnated Gore-Tex membranes. J. Electrochem. Soc., 1990, 137(2), 510-517.

[12] Liu, C.; Martin, C.R. Ion-transporting composite membranes. III. Selectivity and rate of ion transport in Nafion-impregnated GoreTex membranes prepared by a high temperature solution casting method. J. Elctrochem. Soc., 1990, 137(12), 3114-3120.

[13] Bahar, B.; Hobson, A.R.; Kolde, J.A. Ultra-thin film integral composite membrane. U.S. Patent 5,547,551, 1996.

[14] Nouel, K.M.; Fedkiw, P.S. Electrochim Acta, 1998, 43, 2381-2387.

[15] Bahar, B.; Hobson, A.R.; Kolde J.A. Electrode apparatus containing an integral composite membrane. U.S. Patent 5,635,041, 1997.

[16] Liu, F.; Yi, B.; Xing, D.; Yu, J.; Zhang H. Nafion/PTFE composite membranes for fuel cell applications. J. Membr. Sci., 2003, 212, 213-223.

[17] Lin, H.L.; Yu, T.L.; Shen, K.S.; Huang, L.N. Effect of Triton-X on the preparation of nafion/PTFE composite membranes. J. Membr. Sci., 2004, 237, 1-7.

[18] Yu, T.L.; Lin, H.L.; Shen,K.S.; Chang, Y.C.; Jung, B.; Huang, J.C. Nafion/PTFE composite membranes for fuel cell applications. $J$. Polym. Res., 2004, 11, 217-224.

[19] Lin, H.L.; Yu, T.L.; Chang, W.K.; Cheng, C.P.; Hu C.R.; Jung G.B. Preparation of a low proton resistance PBI/PTFE composite membrane. J. Power Sourc., 2007, 164, 481-487.

[20] Lin, H.L.; Chen, Y.C.; Li, C.C.; Cheng, C.P.; Yu, T.L. Preparation of PBI/PTFE Composite Membranes from PBI in N,N'-Dimethyl acetamide Solutions with Various Concentrations of LiCl. J. Power Sourc., 2008, 181, 228-236.

[21] Ueda, M.; Sato, M.; Mochizuki, A. Poly(benzimidazole) synthesis by direct reaction of diacids and diamines. Macromolecules, $\mathbf{1 9 8 5}$, 18(8), 2723-2726.

[22] Choe, E.W.; Choe, D.D. In Polymer Materials Encyclopedia; Salamone J.C. Ed.; CRC Press: New York, 1996.

[23] Kishbaugh, A.J.; MaHugh, A.J. A rheo-optical study of shearthickening and structure formation in polymer solutions. Part II: 
Light scattering analysis. Rheol. Acta, 1993, 32(1), 9-24; 32(2), 115-131.

[24] Bokias, G.; Hourdet, D.; Iliopoulos I. Positively charged amphiphilic polymers based on poly( $\mathrm{N}$-isopropylacrylamide): phase behavior and shear-induced thickening in aqueous solution. Macromolecules, 2000, 33(9), 2929-2935.
[25] Ma, S.X.; Cooper, S.L. Shear thickening aqueous solutions of hydrocarbon end-capped poly(ethylene oxide). Macromolecules, 2001, 34(10), 3294-3301.

(C) Yu and Lin; Licensee Bentham Open.

This is an open access article licensed under the terms of the Creative Commons Attribution Non-Commercial License (http://creativecommons.org/licenses/by$\mathrm{nc} / 3.0 /$ ) which permits unrestricted, non-commercial use, distribution and reproduction in any medium, provided the work is properly cited. 